УДК 323.2(355.1+355.2)

https://doi.org/10.34142/24130060.2020.20.1.17

\title{
АРМІЯ \& СУСПІЛЬСТВО: ДО ВИЗНАЧЕННЯ СТРАТЕГІї ДОСЛІДЖЕННЯ
}

\author{
Ю. О. Тяпкіна
}

Харківський національний педагогічний університет імені Г.С. Сковороди

Стаття присвячена визначенню ефективної стратегії дослідження взаємодії між армією і суспільством у нових соціокультурних та соціально-політичних контекстах його розвитку.

У контексті досягнення зазначеної мети аналізуються найбільш відомі в сучасному сочіально-політичному дискурсі дослідницькі стратегії аналізу взаємодії між суспільством і армією:

через побудову концептуальних моделей взаємозв'язку, щзо існує між силовими структурами і політикою в умовах різних політичних режимів;

через розкриття функціонального потенціалу військового інституту в різних соціально-політичних і соціокультурних контекстах розвитку сочіуму.

Обгрунтовується, щуо за нових умов розвитку сучасного суспільства його взаємовідносини з армією доцільно розглядати з позииї застосування провідних положень неоінституиіонального підходу.

Ключові слова: армія, суспільство, політика, політичний режим, модель, функціональний потенціал, неоінституціоналізм.

\section{АРМИЯ \& ОБЩЕСТВО: К ОПРЕДЕЛЕНИЮ СТРАТЕГИИ ИССЛЕДОВАНИЯ}

\section{Ю. О. Тяпкина}

Статья посвящена определению эффективной стратегии исследования взаимодействия между армией и обществом в новых сочиокультурных и сочиильнополитических контекстах его развития.

В процессе достижения указанной цели анализируются наиболее известные в современном сочиально-политическом дискурсе исследовательские стратегии анализа взаимодействия между обществом и армией:

с помощью построения концептуальных моделей взаимосвязи, существующей между силовыми структурами и политикой в условиях различных политических режимов;

через раскрытие функционального потенциала военного института в различных социально-политических и социокультурных контекстах развития социума.

Обосновывается, что в новых условиях развития современного общества его взаимоотношения с армией целесообразно рассматривать с позиции применения ведущих положений неоинституционального подхода.

Ключевые слова: армия, общество, политика, политический режим, модель, функциональный потенцииал, неонституционализм.

(C) Ю.О. Тяпкіна, 2020 


\section{ARMY \& SOCIETY: TOWARDS A RESEARCH STRATEGY}

\section{Y. Tiapkina}

The article is devoted to the definition of an effective strategy for studying the interaction between the army and society in the new sociocultural, social and political contexts of its development.

In the process of achieving this goal, the most famous research strategies in modern social and political discourse for analyzing the interaction between society and the army are analyzed:

by building conceptual models of the relationship that exists between the security forces and politics in the context of various political regimes;

through the disclosure of the functional potential of the military institution in various socio-political and socio-cultural contexts of the development of society.

As well-known theoretical constructions of the first direction, the model proposals of A.R. Lekhem, M. Trebin, U. Ilnitska.

As examples of the second direction in the study of the relationship between society and military structures, the theoretical developments of domestic researchers are considered.

It is substantiated that all two versions of scientific intelligence in this direction leave out of the attention of researchers the study of the relationship of various elements of the military bloc with other social structures, and above all institutions and quasi-institutions of civil society.

It is substantiated that in the new conditions of development of modern society, its relationship with the army should be considered from the position of applying the leading provisions of the neo-institutional approach.

It is this research strategy that allows us to consider the army at the same time as a kind of organization that performs specific functions to achieve state goals, and as a system that carries out activities in the direction of satisfying its specific goals in the context of active interaction with other systemic formations of socio-political reality (in their the number includes institutions and quasi-institutions of civil society).

Key words: army, society, politics, political regime, model, functional potential, neoinstitutionalism.

Постановка проблеми. Проблемне поле армії (військового інституту) виступає традиційним предметом соціально-політичних досліджень як серед представників зарубіжного наукового співтовариства, так і вітчизняного. Природно, що інтерес до його елементів різко зростає в періоди військових дій, криз і глибоких трансформацій суспільного життя, коли активізується безпосередня діяльність цього соціально-політичного інституту.

Сьогодні, в період, коли і світове співтовариство країн в цілому, і українське суспільство зокрема, переживають цілу серію кризових ситуацій (від локального до глобального масштабу), очевидно, що роль військових структур не тільки зростає, але їх функції суттєво трансформуються, і ці всі процеси вимагають відповідного рівня експлікації. I, очевидно, що всі нові 
дослідницькі розвідки в цьому напрямі вимагають уточнення, перш за все, моменту змісту і форми взаємодії армії і суспільства в нових умовах розвитку останнього.

Аналіз актуальних досліджень. Результати дослідження різних аспектів взаємодії військових структур та суспільства містяться вже в працях давньокитайських і давньогрецьких мислителів. Сучасні інтерпретації цього процесу викладені в публікаціях зарубіжних дослідників (зокрема, Б. Абрахамсона, М. Едмондса, Х. Лассуела, А. Р. Лукхема, С. Хантінгтона, М. Яновіца та ін.) та вітчизняних науковців (Є. Афоніна, О. Безрука, У. Ільницької, О. Панфілова, В. Смолянюка, М. Требіна та ін.) (Bezruk, 2012; Ilnytska, 2008; Smolianiuk, red., 2002; Rudia, 2014; Trebin, 2017; Trebin, 2004; Luckham, 1971).

Слід зауважити, що найчастіше взаємодія між суспільством і армією розглядається в двох напрямках:

через побудову концептуальних моделей взаємозв'язку, що існує між силовими структурами і політикою в умовах різних політичних режимів (Bezruk, 2012; Ilnytska, 2008; Smolianiuk, red., 2002; Trebin, 2017; Trebin, 2004; Luckham, 1971);

через розкриття функціонального потенціалу військового інституту в різних соціально-політичних і соціокультурних контекстах розвитку соціуму (Bezruk, 2012; Denysenko ta Tiapkina, 2019; Smolianiuk, red., 2002; Rudia, 2014; Trebin, 2004).

Виходячи $з$ цього, мета статті - визначити найбільш ефективну стратегію дослідження взаємодії між армією і суспільством в нових контекстах розвитку останнього.

Виклад основного матеріалу. Для досягнення поставленої мети пропонується, перш за все, проаналізувати і порівняти дві вищеозначені стратегії дослідження.

Представниками сучасного політологічного дискурсу сконструйовано кілька варіантів груп моделей, що інтерпретують взаємозв'язок між армією і 
політикою. Узагальнений погляд на ці пропозиції міститься в статті американського дослідника А. Р. Лукхема «Порівняльна типологія цивільновійськових відносин» (1971). Автором виділяються дев’ять моделей, кожна 3 яких відображає певні особливості відносин між державою та ії військовим інститутом.

Перша модель - «Об’єктивний контроль», базується на високому рівні збалансованості військової моці та цивільної влади. Контроль над військовими структурами здійснюється 3 боку цивільної влади. Модель притаманна державам ліберальної демократії (зокрема, країнам Західної Європи, США, Канаді).

Друга модель - «Поліцейський контроль», існує в умовах сильної цивільної влади та середнього рівня військової структури. На практиці сформувалася в таких країнах як Японія, Ірландія, Швеція.

Третя модель - «Апаратний контроль», формується за умов: а) зміни політичного режиму; б) приходу до влади у контексті перемоги в воєнних діях командування партизанської армії, що функціонує під керівництвом політичної партії; в) рецепції цієї форми взаємодії під контролем держави, в якій ця модель вже функціонує на практиці. Контроль над військовими структурами 3 великим силовим потенціалом здійснює керівний апарат правлячої партії. Ця модель ефективно функціонувала в СРСР, Китаї та країнах Східної Свропи в період з 1945 р. по 1990 р.

Четверта модель - а) «Озброєна нація» та б) «Революційна озброєна нація». Перший варіант моделі існує за умов сильної цивільної влади, яка повністю контролює діяльність також сильних військових структур у контексті орієнтації на цінності громадянського суспільства (Ізраїль). Другий - за умов сильної цивільної влади, яка повністю контролює діяльність досить слабких військових сил, сформованих у результаті здійснення соціальних революцій та ведення національно-визвольних воєн та орієнтованих на збереження національної ідеї та цінностей (Алжир, В’єтнам, Куба). 
П’ята модель - «Суб'єктивний контроль», заснована на певній ідентичності військової та цивільної влади, тобто, керівництво державного апарату країни одночасно є командуючими їі збройними силами. Модель функціонувала в XVIII ст. у країнах Свропи та у XIX ст. - в країнах Латинської Америки.

Шоста модель - «Гарнізованний стан», існує за умов домінування військових структур над усіма сферами суспільства, на всіх рівнях та напрямах прийняття політичних рішень (від внутрішньодержавних до зовнішньо). Модель на практиці була реалізована у більшості країн Західної Європи під час Першої та Другої світових війн.

Сьома модель - а) «Патерналістська модель» та б) «Постколоніальна патерналістська модель». Перший різновид моделі орієнтований на активне втручання представників військових структур у політичне життя країни за умов слабкої цивільної влади (низка країн Північної Африки та Латинської Америки). Другий - передбачає, що певна цивільна влада існує виключно у контексті постійної підтримки 3 боку силових структур (низка країн Центральної Африки).

Восьма модель - «Преторіанська держава», існує за умов слабкої цивільної влади та сильної або середньої моці збройних сил, представники яких власні політичні інтереси не ідентифікують 3 національними, державними інтересами. Контроль над державою повністю здійснюється 3 боку військових в контексті звернення до постійної загрози застосування збройного насильства (низка країн Північної та Центральної Африки).

Дев’ята модель - «Політичний вакуум», базується на існуванні в державі одночасно як слабкої цивільної влади, так й слабо організованих та малочисельних збройних сил. Контроль будь-якої структури над іншою повністю відсутній. Модель на практиці існувала в окремі періоди в Конго та Нiгеріï (Luckham, 1971).

Інший варіант класифікації моделей взаємодії армї та політики в контексті розгляду різних політичних режимів міститься в публікаціях цілої 
низки вітчизняних дослідників (зокрема, О. Безрука (2012), У. Ільницької (2008), В. Смолянюка (2002)).

Авторами пропонується за умов існування тоталітарного режиму виокремлювати можливу реалізацію на практиці трьох варіантів моделей відносин армії і політичної влади: партійно-тоталітарної, напіввійськовототалітарної; військовототалітарної (або стратократичної). «За партійнототалітарної моделі (сталінський режим), - стверджує У. Ільницька 3 посиланнями на дослідження В. Смолянюка, - армія $\epsilon$ повністю підпорядкованим, підконтрольним об’єктом партійної влади Напіввійськовототалітарна модель (гітлерівський режим) передбачає здійснення політичної влади правлячою елітою, яка становить або органічний компонент політичної влади, або найбільш потужну силу тиску на неї... Військово-тоталітарна, або стратократична (від грецького «стратос» - сила) модель передбачає здійснення армією монопольного політичного керівництва через усунення від влади правлячої партії. Внаслідок цього встановлюється військово-тоталітарний режим (приклади - Бразилія, Греція, Чилі після Другої світової війни)» (Ilnytska, 2008).

За умов функціонування авторитарного політичного устрою цивільно-авторитарну, напіввійськово-авторитарну та військово-авторитарну. Для кожної моделі характерно, що, з одного боку, «армія в них є об'єктом, що повністю підпорядкований авторитарній владі», а 3 іншого - існує певна політична самостійність та активність військового інституту. «Використання бойового потенціалу армії, функціонування іiі як самостійної сили, стверджує українська дослідниця, - можливе у таких варіантах: армія виходить із підпорядкування уряду і здійснює військовий переворот; армія використовується окремими політичними силами для тиску на уряд; армія діє як механізм захисту нелегітимної влади (в цьому випадку керівництво країни за допомогою армії дисциплінує i тримає у покорі народ); армія використовується як інструмент придушення масових заворушень (армія виконує невластиву ій функцію охорони громадського порядку); армія 
виступає як сила, що діє самостійно для забезпечення життєдіяльності війська і для захисту військовослужбовців і їх сімей» (Ilnytska, 2008).

У межах становлення та подальшого розвитку демократичного політичного режиму у відповідних державах формується та реалізується в практичній площині демократична модель взаємодії армії та політики. Для цієї побудови характерно, що збройні сили не беруть участь у боротьбі за владні повноваження, підпорядковані та підконтрольні цивільному демократично обраному уряду та функціонують в інтересах народу і держави у контексті реалізації основоположного принципу демократії - верховенства права.

Дещо інший варіант класифікації моделей взаємозв’язку армії та політики у сучасному суспільстві пропонується в працях іншого українського дослідника - М. Требіна. Так, в його монографії «Армія та суспільство: соціально-філософський аналіз взаємодії в умовах трансформації» (2004) останні пропонується розробляти в контексті визначення так званого «модуса буття», що «продукує відповідний тип політичного устрою суспільства» (Trebin, 2004, с. 195). Під цим концептом пропонується розглядати «деяку соціокультурну матрицю, складовими елементами якої $\epsilon$ : ментальність, традиції, система правил осмислення навколишньої дійсності і діяльності щодо іiі перетворення, домінуючі духовні цінності, релігія тощо» (Trebin, 2004, c. 195).

Дослідником виокремлюються три «модуса буття»:

тоталітарний, якому «притаманні абсолютний контроль держави над усіма сферами громадського життя, незмінність законів функціонування, примат суспільства над індивідом, зневажання прав і свобод громадян, протиставлення себе всьому іншому світу» (Trebin, 2004, с. 196);

авторитарний, що «базується на прагненні максимально підкорити своєму впливу партнерів по взаємодії і спілкуванню. Для нього характерна агресивність, завищена самооцінка i рівень домагань, схильність до дотримання стереотипів, слабка рефлексія тощо (Trebin, 2004, с. 197); 
демократичного суспільства, який визначається насамперед, формуванням громадянського суспільства, існуванням політичного плюралізму, ствердженням високої політичної культури» (Trebin, 2004, с. 210).

У контексті застосування цих «модусів буття» дослідником виокремлюються такі можливі варіанти взаємодії армії і політики.

У межах «тоталітарного модуса буття» - a) «комуністична модель» та б) «фашистська модель», в яких перевага надається зовнішньополітичним цілям, методам насильницького поширення політичного ладу на інші суспільства за допомогою військової сили.

У межах «авторитарного модуса буття» - «стратократична модель», у якій армія здійснює правління іншими гілками влади. Тут влада обмежує політиків або замінює політичні структури військовими (режим «чорних» полковників у Греції).

У межах «модуса буття демократичного суспільства» - «демократична модель», де взаємовідносини армії і суспільства грунтуються виключно на принципах демократичного законодавства, і військовий інститут знаходиться в підпорядкуванні та під ефективним контролем останнього.

Очевидно, що вищезазначені варіанти класифікації взаємодії армії та політики:

a) не суперечать один одному, а лише доповнюють результати один одного;

б) всебічно орієнтовані і здатні інтерпретувати саме взаємовідносини між державною владою та військовими структурами (зрозуміло, що це випливає навіть із загальних назв конструкцій). Тобто, поза відповідною експлікацією знаходяться відносини між армією та іншими інститутами та інституціями суспільства, зокрема, структурами громадянського суспільства.

Щодо другого напряму вивчення взаємодії армії та суспільства, сформованого у сучасному соціально-політичному дискурсі - через розкриття функціонального потенціалу військового інституту в різних 
соціально-політичних і соціокультурних контекстах розвитку соціуму, то, очевидно, що він базується на застосуванні провідних положень двох теоретичних побудов політичної науки - структурного-функціоналізму та системного аналізу.

Відповідно до них, військовий інститут розглядається як певна поліфункціональна структура\система, як 3 зовнішніми, так і внутрішніми імперативами.

Систему зовнішніх функцій складає діяльність військових структур у напряму забезпечення суверенітету держави; збереження недоторканності кордонів (як власної держави, так й ¥ї союзників), вирішення проблем, що мають загальнолюдське значення та ін.

Систему внутрішніх імперативів формують такі дії збройних сил держави: «забезпечення влади панівної соціальної групи, припинення i запобігання внутрішнім соціальним конфліктам, які загрожують розвалом державі, тобто, збереження ii територіальної цілісності, виховання у громадян готовності захисту своєї Батьківщини, формування навичок моральної поведінки в подальшій трудовій діяльності, моральнопсихологічна підготовка молоді до життєвих труднощів» (Rudia, 2014, c. 160).

Очевидно, що вищезазначені теоретичні розвідки певним чином розкривають особливості взаємодії армії з іншими соціальними інститутами, зокрема, з освітою та родиною. Але, як й у ситуації з вищезазначеними моделями, поза увагою аналізу залишаються стан та специфіка взаємовідносин різних елементів силового блоку зі структурами саме громадянського суспільства.

За цих обставин пропонується для підвищення рівня інтерпретації відносин між армією та суспільством у контексті нових умов його розвитку (насамперед, подальшої демократизації) звернутися до евристичного потенціалу неоінституціоналізму, який дозволяє «розглядати армію одночасно i як певну організацію, яка виконує конкретні функції щодо 
досягнення державних цілей, i як систему, яка здійснює діяльність у напрямку задоволення своїх специфічних цілей в контексті активної взаємодії 3 іншими системними утвореннями соціально-політичної реальності» (Denysenko ta Tiapkina, 2019, с. 82).

Висновки i перспективи подальших досліджень. Армія $\epsilon$ невід’ємною структурною складовою (атрибутом) сучасного суспільства, яку, насамперед, пов'язують 3 політичною владою, справедливо стверджуючи, що цей зв’язок зміцнюють такі чинники, як змістовні особливості військового інституту (армія $\epsilon$ найбільш мобільною, організованою та дисциплінованою структурою держави) та специфіка його функціонального потенціалу (армія $є$ гарантом збереження політичної стабільності правлячого режиму; армія забезпечує досягнення тих політичних цілей, які задає керівництво держави; у випадках політичної нестабільності лише армія здатна оперативно мобілізовуватись та реагувати на ситуацію; армія на відміну від інших політичних інституцій не може просто ігнорувати кризові події, які є загрозливими для самої держави) (Bezruk, 2012). Але окрім взаємовідносин з політичною сферою, існування силових структур у просторі сучасного соціуму характеризують зв'язки 3 іншими його життєвими полями й відповідними інститутами та інституціями. За цих обставин, зрозуміло, підвищується рівень вимог до пізнавального інструментарію сучасної політичної науки.

Враховуючи зміст та результати традиційних стратегій дослідження взаємодії армії та суспільства, які презентовані у сучасному соціальнополітичному дискурсі, пропонується нові варіанти дослідницьких розвідок розробляти у контексті активного звернення до головних положень неоінституціалізму. Останній розглядається як «певний набір аналітичних принципів, який дозволяє продуктивно вивчати найбільш важливі суспільнополітичні явища i процеси як мікро-, так i макрорівня, а головне обгрунтувати генетичний зв’язок між ними» (Buldovych, 2017, с. 23-24). 


\section{ЛITЕРАТУРА}

1. Безрук, О. О., 2012. Армія як специфічний канал політичної мобільності в контексті сучасних політичних режимів. Політологічні записки: зб.наук.пращь, 1(5). с. 343-352.

2. Бульдович, П. В., $2017 . \quad$ Проблема ідентифікації неоінституціонального підходу в сучасній політичній науці. Політичне життя, 3, с. 21-25.

3. Ільницька, У. В., 2008. Армія і політика: моделі взаємодіi в умовах різних політичних режимів. [online] Видавництво Національного університету «Львівська політехніка». Доступно: http://ena.lp.edu.ua:8080/bitstream/ntb/390/1 /36.pdf [Дата звернення 19 Жовтень 2019].

4. Денисенко, І. Д. та Тяпкіна, Ю. О., 2019. Армія сучасної держави: визначення стратегії дослідження. Сучасне суспільство: політичні науки, сочіологічні науки, культурологічні науки, 1(17), с. 7383.

5. Смолянюк, В. Ф. ред., 2002. Політологія: Підручник для курсантів вищих військових навчальних закладів Збройних сил України. Вінниця: Нова книга.

6. Рудя, Р. Г., 2014. Сучасна армія в умовах трансформаційних змін: інституціональний аналіз. Сучасне суспільство: політичні науки, сочіологічні науки, культурологічні науки, 2, с. 157166.

7. Требін, М. П., 2017. Армія і суспільство: осмислення взаємодії. Вісник Національного університету «Юридична академія України імені Ярослава Мудрого». Політологія, 2(33), с. 138-162.

8. Требін, М. П. 2004. Армія та суспільство: соиіально-філософський аналіз взаємодії в умовах трансформачії: монографія. Харків: Видавничий Дім «Інжек».

9. Luckham, A. R., 1971. Comparative Typology of Civil-Military Relations. Government and Opposition, [online] 6(1), p. 5-35 Доступно: https://www.jstor.org/stable/44482735?seq= 1 [Дата звернення 20 Жовтень 2019].

\section{REFERENCES}

1. Bezruk, O. O., 2012. Armiia yak spetsyfichnyi kanal politychnoi mobilnosti $\mathrm{v}$ konteksti suchasnykh politychnykh rezhymiv. Politolohichni zapysky: zb.nauk.prats, 1(5). s. 343-352.

2. Buldovych, P. V., $2017 . \quad$ Problema identyfikatsii neoinstytutsionalnoho pidkhodu $\mathrm{v}$ suchasnii politychnii nautsi. Politychne zhyttia, 3, s. 21-25.

3. Ilnytska, U. V., 2008. Armiia i polityka: modeli vzaiemodii $v$ umovakh riznykh politychnykh rezhymiv. [online] Vydavnytstvo Natsionalnoho universytetu «Lvivska politekhnika». Dostupno: http://ena.lp.edu.ua:8080/bitstream/ntb/390/1 /36.pdf [Data zvernennia 19 Zhovten 2019].

4. Denysenko, I. D. ta Tiapkina, Yu. O., 2019. Armiia suchasnoi derzhavy: vyznachennia stratehii doslidzhennia. Suchasne suspilstvo: politychni nauky, sotsiolohichni nauky, kulturolohichni nauky, 1(17), s. 73-83.

5. Smolianiuk, V. F. red., 2002. Politolohiia: Pidruchnyk dlia kursantiv vyshchykh viiskovykh navchalnykh zakladiv Zbroinykh syl Ukrainy. Vinnytsia: Nova knyha.

6. Rudia, R. H., 2014. Suchasna armiia v umovakh transformatsiinykh zmin: instytutsionalnyi analiz. Suchasne suspilstvo: politychni nauky, sotsiolohichni nauky, kulturolohichni nauky, 2, s. 157-166.

7. Trebin, M. P., 2017. Armiia i suspilstvo: osmyslennia vzaiemodii. Visnyk Natsionalnoho universytetu «Iurydychna akademiia Ukrainy imeni Yaroslava Mudroho». Politolohiia, 2(33), s. 138-162.

8. Trebin, M. P. 2004. Armiia ta suspilstvo: sotsialno-filosofskyi analiz vzaiemodii $v$ umovakh transformatsii: monohrafiia. Kharkiv: Vydavnychyi Dim «Inzhek».

9. Luckham, A. R., 1971. Comparative Typology of Civil-Military Relations. Government and Opposition, [online] 6(1), p. 5-35 Dostupno: https://www.jstor.org/stable/44482735?seq= 1 [Data zvernennia 20 Zhovten 2019].

\section{Інформація про автора}

Тяпкіна Юлія Олегівна - аспірантка кафедри політології, соціології і культурології Харківського національного педагогічного університету імені Г.С. Сковороди; e-mail: yuliaolegovnat@gmail.com; ORCID: http://orcid.org/0000-0002-3240-3555. 